\title{
SJR
}

Home

\section{Water Environment Research}

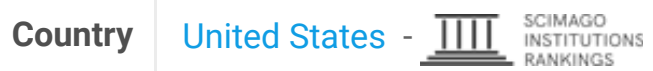 \\ Subject Area and Environmental Science \\ Category Ecological Modeling \\ Environmental Chemistry \\ Pollution \\ Waste Management and Disposal \\ Water Science and Technology \\ Publisher Water Environment Federation \\ Publication type Journals \\ ISSN 10614303,15547531
}
Coverage $1992-2020$
Scope Published since 1928, Water Environment Research (WER) is an international multidisciplinary water resource management journal for the dissemination of fundamental and applied research in all scientific and technical areas related to water quality and resource recovery. WER's goal is to foster communication and interdisciplinary research between water sciences and related fields such as environmental toxicology, agriculture, public and occupational health, microbiology, and ecology. In addition to original research articles, short communications, case studies, reviews, and perspectives are encouraged. Keywords: - activated carbon- activated sludge- adsorption- agriculture- algae- biodegradation- biological treatment- biosolids- collection systems/sewers- drinking water- groundwater- industrial waste- kinetics- membrane technology- modeling- nitrogen removal- optimization- oxidation- personal care products- pharmaceuticals- physical and chemical treatment- remediation- resource recovery- reuse- sediments- sludge- soil- sorption- stormwater- surface water- toxicology- wastewater treatment

? Homepage

How to publish in this journal

Contact

Join the conversation about this journal

Quartiles

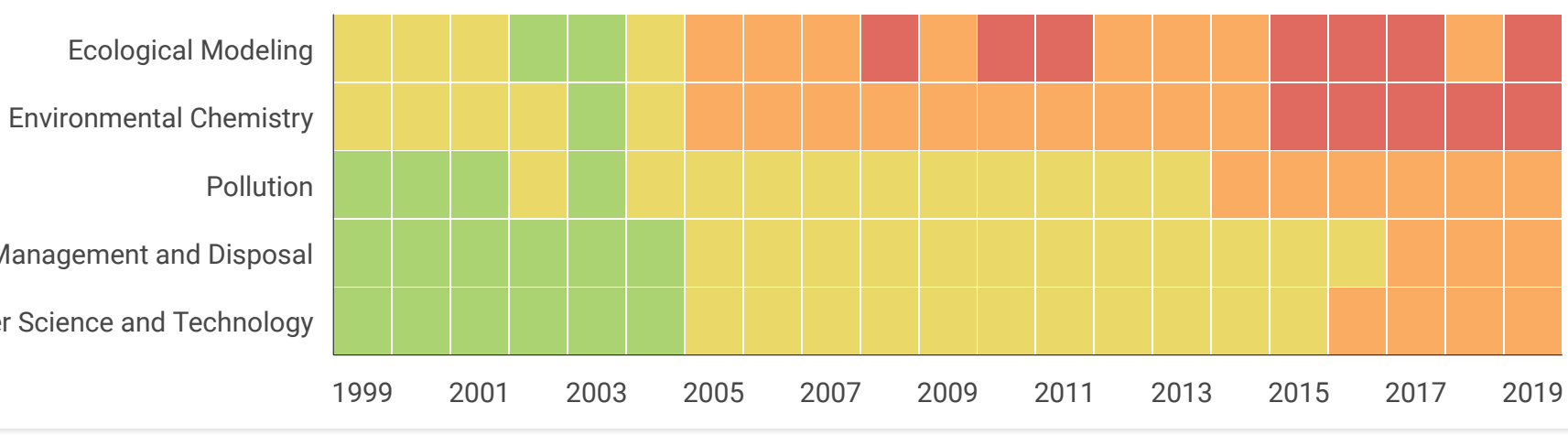




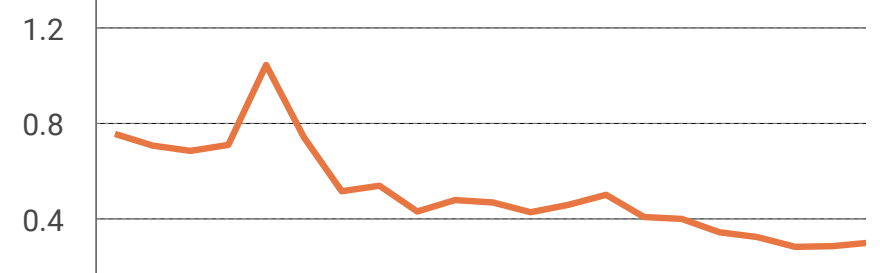

\section{Total Cites Self-Cites}

800

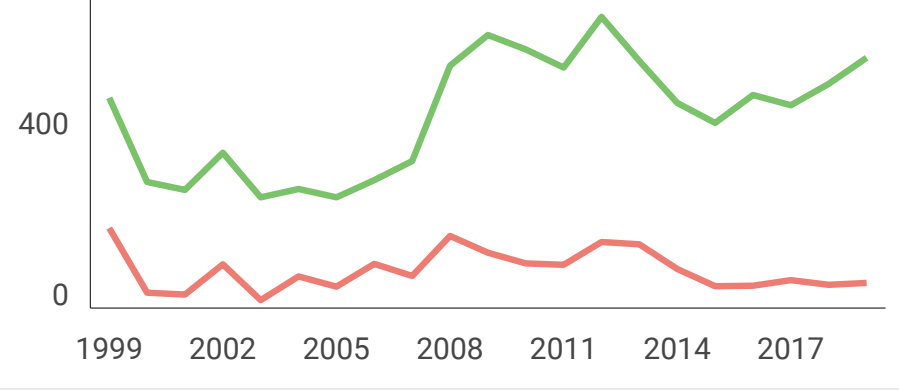

\section{External Cites per Doc}

Cites per Doc

1.6

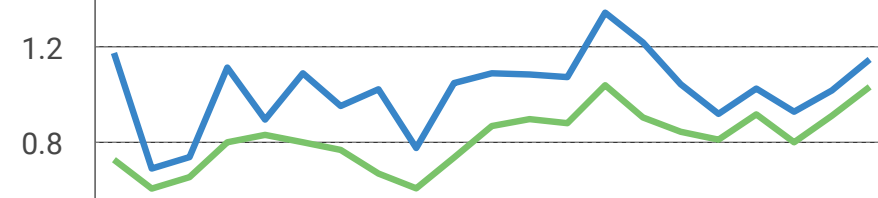

0.4

$\begin{array}{lllllll}1999 & 2002 & 2005 & 2008 & 2011 & 2014 & 2017\end{array}$

Citable documents Non-citable documents $\quad+$ 600

300

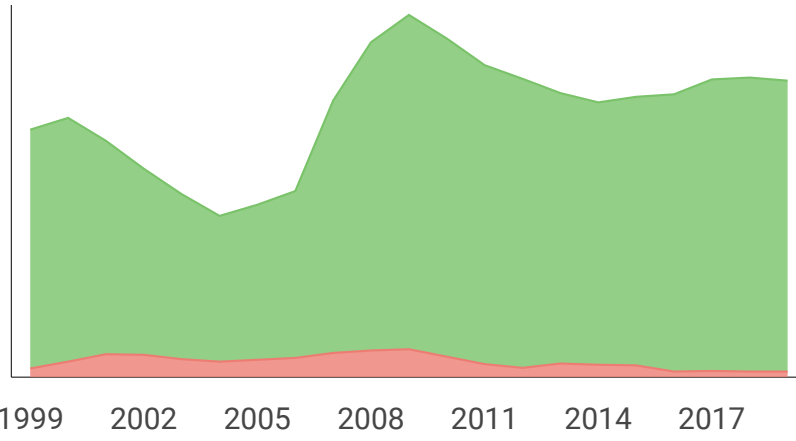

\section{Water Environment}

Research

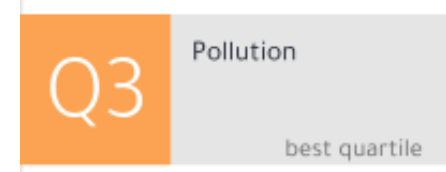

SJR 2019

0.3

powered by scimagojr.com

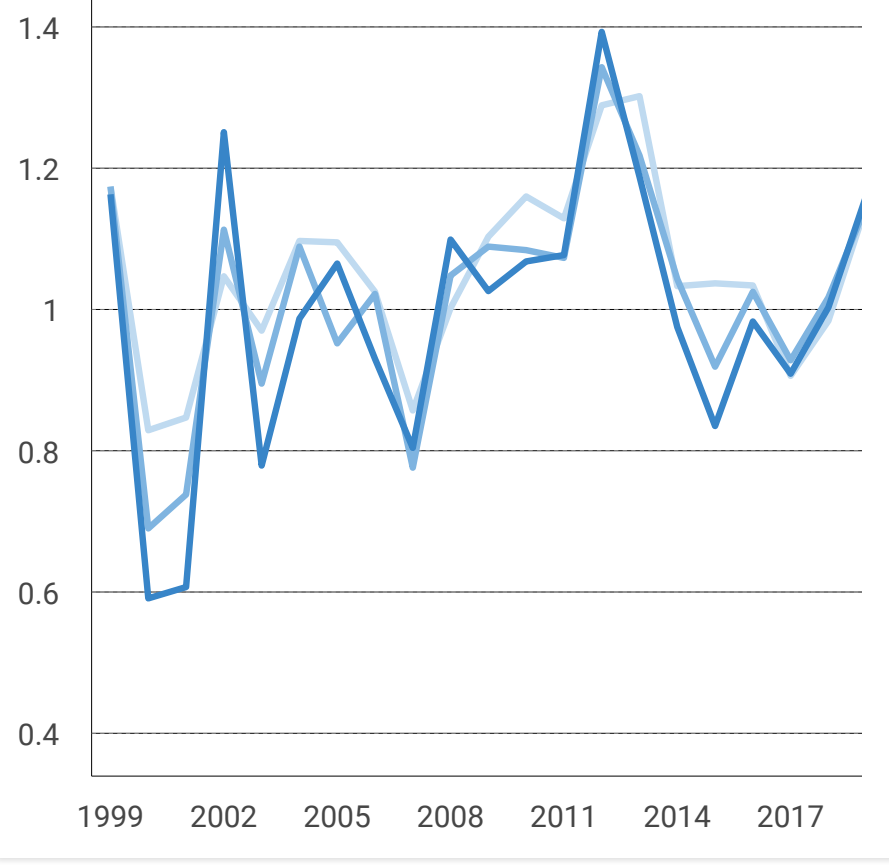

\% International Collaboration

40

20

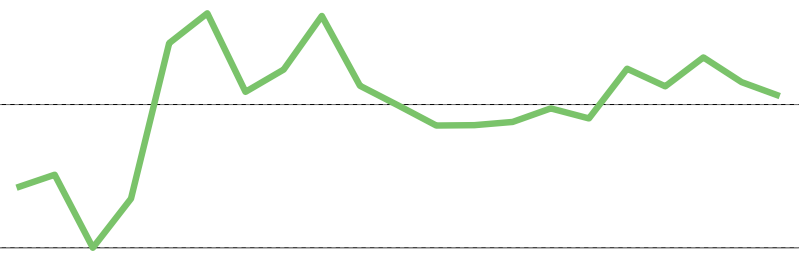

$\begin{array}{lllllll}1999 & 2002 & 2005 & 2008 & 2011 & 2014 & 2017\end{array}$

Cited documents Uncited documents 600

300

$\begin{array}{lllllll}1999 & 2002 & 2005 & 2008 & 2011 & 2014 & 2017\end{array}$ 


\section{Source details}

\section{Water Environment Research}

Formerly known as: Research Journal of the Water Pollution Control Federation

Scopus coverage years: from 1992 to Present

Publisher: Water Environment Federation

ISSN: 1061-4303 E-ISSN: 1554-7531

Subject area: Environmental Science: Water Science and Technology Environmental Science: Waste Management and Disposal

Environmental Science: Pollution Environmental Science: Ecological Modeling View all $\checkmark$

0.375

1.7

SJR 2019

0.301

CiteScore 2019

(i)

\begin{tabular}{l|l|l|l|l} 
View all documents $>\quad$ Set document alert $\quad \square$ Save to source list Journal Homepage
\end{tabular}

CiteScore CiteScore rank \& trend Scopus content coverage

CiteScore 2019

$1.7=\frac{1,083 \text { Citations } 2016-2019}{620 \text { Documents } 2016-2019}$

Calculated on 06 May, 2020
CiteScoreTracker 2020 (i)

$2.3=\frac{1,489 \text { Citations to date }}{636 \text { Documents to date }}$

Last updated on 10 January, 2021 • Updated monthly

CiteScore rank 2019 (i)

Category Rank Percentile

\begin{tabular}{l}
\hline Environmental \\
Science \\
$\begin{array}{l}\text { Later Science } \\
\text { and Technology }\end{array}$ \\
$\begin{array}{l}\text { Environmental } \\
\text { Science }\end{array}$ \\
$\begin{array}{l}\text { W Waste } \\
\text { Management } \\
\text { and nimmand }\end{array}$ \\
\hline
\end{tabular}

View CiteScore methodology $>$ CiteScore FAQ $>$ Add CiteScore to your site $\mathbb{O}$

$\begin{array}{lll}\text { About Scopus } & \text { Language } & \text { Customer Service } \\ \text { What is Scopus } & \text { 日本語に切り替える } & \text { Help } \\ \text { Content coverage } & \text { 切换到简体中文 } & \text { Contact us } \\ \text { Scopus blog } & \text { 切換到繁體中文 } & \\ \text { Scopus API } & \text { Русский язык } & \end{array}$



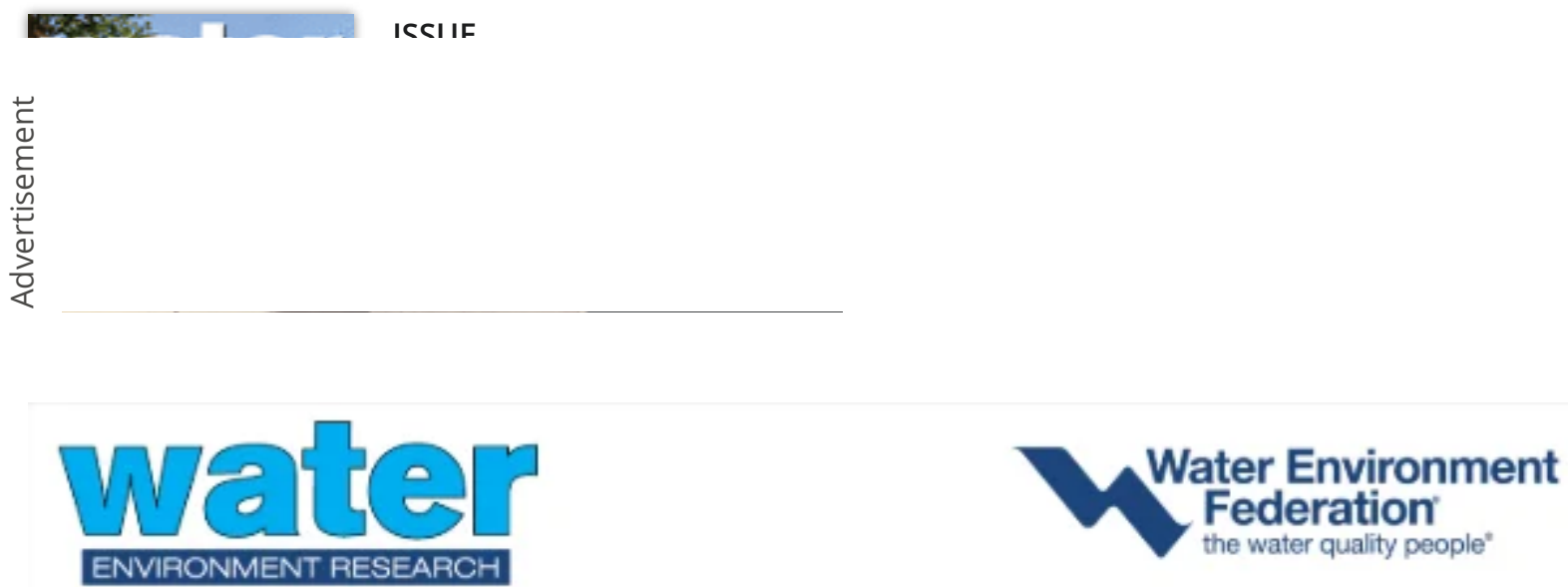

Journal of the Water Environment Federation

Editor in Chief Jason He

Impact factor: 1.369

2019 Journal Citation Reports (Clarivate Analytics): 46/53 (Engineering, Environmental) 219/265 (Environmental Sciences) 14/22 (Limnology) 69/94 (Water Resources)

Online ISSN: 1554-7531

\section{Thank You}

Pages: 195 | First Published: 01 March 2018

Full text | PDF | Request permissions 


\section{Research Papers}

Anaerobic Digestion Model No. 1 Simulation of High Solids Anaerobic Digestion with Feasibility Study for El Gabal El Asfar Water Resource Recovery Facility: Aboulfotoh Ahmed M. Aboulfotoh

Pages: 197-205 | First Published: 01 March 2018

Abstract $\mid$ Full text $\mid$ PDF $\mid$ References | Request permissions

Application of the Risk-Based Early Warning Method in a Fracture-Karst Water Source, North China

Yongli Guo, Qing Wu, Changsuo Li, Zhenhua Zhao, Bin Sun, Shiyi He, Guanghui Jiang, Yuanzheng Zhai, Fang Guo

Pages: 206-219 | First Published: 01 March 2018

Abstract | Full text $\mid$ PDF $\mid$ References | Request permissions

Assessment of Water Physicochemical Parameters in the Strîmtori-Firiza Reservoir in Northwest Romania: Dippong et al.

Thomas Dippong, Cristina Mihali, Daniel Năsui, Zoiţa Berinde, Claudia Butean

Pages: 220-233 | First Published: 01 March 2018

Abstract | Full text | PDF | References | Request permissions

\section{Spatial Variation of Metals in the Batang Arau River, West Sumatera, Indonesia}

Shinta Indah, Denny Helard, Marjani Amajida Herfi, Hukama Hamid

Pages: 234-243 | First Published: 01 March 2018

Abstract | Full text $\mid$ PDF | References | Request permissions

Modeling Storm-Influenced Suspended Particulate Matter Flocculation Using a TideWave-Combined Biomineral Model: Chen et al.

Peihung Chen, Jason C. S. Yu, Michael Fettweis

Pages: 244-257 | First Published: 01 March 2018

Abstract | Full text | PDF | References | Request permissions 
Tools for Metagenomic Analysis at Wastewater Treatment Plants:

Application to a Foaming Episode: Rosso et al.

Gretchen E. Rosso, Jeffrey A. Muday, James F. Curran

Pages: 258-268 | First Published: 01 March 2018

Abstract | Full text $\mid$ PDF $\mid$ References | Request permissions

Liquid-Gas Mass Transfer of Volatile Substances in an Energy Dissipating Structure:

Matias et al.

Natércia Matias, Filipa Ferreira, José Saldanha Matos, Asbjørn Haaning Nielsen, Jes Vollertsen

Pages: 269-277 | First Published: 01 March 2018

Abstract | Full text $\mid$ PDF $\mid$ References | Request permissions

Thermal Degradation of Long Chain Fatty Acids: Charuwat et al.

Peerawat Charuwat, Gregory Boardman, Charles Bott, John T. Novak

Pages: 278-287 | First Published: 01 March 2018

Abstract | Full text | PDF | References | Request permissions

Tools

2 Submit an article

A Browse sample issue

- Get Content alerts

It Recommend to a librarian

( Subscribe to this journal

Water Environment Federation

WEFTEC

WEF Committees 

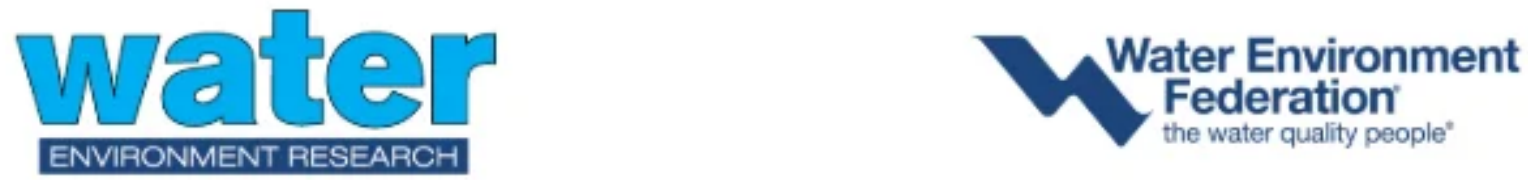

Journal of the Water Environment Federation

Editor in Chief Jason He

Impact factor: 0.825

Online ISSN:1554-7531

Published since 1928, Water Environment Research (WER) is an international multidisciplinary water resource management journal for the dissemination of fundamental and applied research in all scientific and technical areas related to water quality and resource recovery. WER's goal is to foster communication and interdisciplinary research between water sciences and related fields such as environmental toxicology, agriculture, public and occupational health, microbiology, and ecology. In addition to original research articles, short communications, case studies, reviews, and perspectives are encouraged.

Journal of the Water Environment Federation

Editor in Chief Jason He

Impact factor: 1.369

2019 Journal Citation Reports (Clarivate Analytics): 46/53 (Engineering, Environmental) 219/265 (Environmental Sciences) 14/22 (Limnology) 69/94 (Water Resources)

Online ISSN: $1554-7531$

\section{Editorial Board}

\section{Editor-in-Chief}

\section{Zhen (Jason) He}

Washington University, St. Louis

\section{Associate Editors}

\section{Yang Deng}

Montclair State University

\section{Nicole Fahrenfeld}

Rutgers University 


\section{Gnaneswar Gude}

Mississippi State University

\section{Rencun Jin}

Hangzhou Normal University

\section{Chih-Ming (Jimmy) Kao}

National Sun Yat-Sen University

\section{Eakalak Khan}

University of Nevada Las Vegas

\section{Marika Kokko}

Tampere University

Juan Antonio Baeza Labat

The Autonomous University of Barcelona

\section{Brooke Mayer}

Marquette University

\section{Vincenzo Naddeo}

University of Salerno

Britt-Marie Wilén

Chalmers University of Technology

\section{Don Zhao}

Auburn University

\section{Editorial Board}

\section{Irini Angelidaki}

Technical University of Denmark

\section{Charles Bott}

Hampton Roads Sanitation District

\section{Andrea Capodaglio}

University of Pavia

Yves Comeau 
Polytechnique Montréal

Frederic Coulon

Cranfield University

Haydee de Clippier

DC Water

Glen Daigger

University of Michigan

Tim Ellis

Iowa State University, Ames

Val S. Frenkel

Greeley and Hansen

\section{Ramesh Goel}

University of Utah

April Gu

Cornell University

Hongying $\mathrm{Hu}$

Tsinghua University

Zhiqiang $\mathrm{Hu}$

University of Missouri

Woo Hyoung Lee

University of Central Florida

\section{Barry Liner}

Water Environment Federation

\section{Nancy Love}

University of Michigan

\section{Xiaoxia Lu}

Peking University

\section{Yongzhen Peng}

Beijing University of Technology 


\section{Krishna Pagilla}

University of Nevada Reno

Diego Rosso

University of California, Irvine

Raman Saravanane

Pondicherry Engineering College, India

Yiu Fai (Chris) Tsang

The Education University of Hong Kong

Art K. Umble

Stantec

Peter Vanrolleghem

Laval University

\section{Drew Wang}

Virginia Tech.

\section{Hongtao Wang}

Tongji University

Tian Zhang

University of Nebraska, Omaha

\section{Daniel Zitomer}

Marquette University

Tools

a Submit an article

A Browse sample issue

- Get Content alerts

It Recommend to a librarian 


\title{
Spatial Variation of Metals in the Batang Arau River, West Sumatera, Indonesia
}

\author{
Shinta Indah*, Denny Helard, Marjani Amajida Herfi, Hukama Hamid
}

\begin{abstract}
This paper aims to assess metallic pollution in the Batang Arau River, an important source of freshwater supply for local communities in West Sumatera, Indonesia, by applying multivariate statistical techniques. Sampling was conducted at eight stations along the river from March to May 2014. The results indicate that all the metals studied have similar spatial distribution patterns, with an increasing trend in concentration from upstream to downstream. Total concentration of six metals studied upstream, as background concentration, was $1.050 \mathrm{mg} / \mathrm{L}$, and increased to $2.249 \mathrm{mg} / \mathrm{L}$ downstream. Spatial distribution of metals did not show significant variability $(p<0.05)$ for $\mathrm{Cd}, \mathrm{Cr}, \mathrm{Fe}$, and $\mathrm{Pb}$, but $\mathrm{Co}$ and $\mathrm{Mn}$ did. The results of principal component analysis/factor analysis (PCA/ FA) and correlation analysis suggest that $\mathrm{Cd}, \mathrm{Co}$, and $\mathrm{Fe}$ are originated from natural and anthropogenic sources; $\mathrm{Cr}$ and $\mathrm{Pb}$ are derived from natural sources; and $\mathrm{Mn}$ is controlled by anthropogenic sources. Water Environ. Res., 90, 234 (2018).
\end{abstract}

KEYWORDS: Batang Arau River, metals, multivariate analysis, spatial variation.

doi:10.2175/106143017X15131012152780

\section{Introduction}

The Batang Arau River is one of the most important rivers in West Sumatera, Indonesia. It serves as a source of freshwater supply for the local communities to carry out their daily activities such as bathing, laundry, fishing, irrigation recreation, and, most important of all, as a source of drinking water. Therefore, its water quality is of great concern. However, rapid industrialization and urbanization, especially along Batang Arau River, has caused intense pollution to the river (Hong et al., 2012). Contamination of metals in the aquatic-terrestrial ecosystem has attracted great attention in recent years because of their toxicity, abundance, and persistence in the environment, and subsequent accumulation in aquatic habitats. Metals enter the aquatic environment through unregulated and illegal

\footnotetext{
"Department of Environmental Engineering, Faculty of Engineering, Universitas Andalas, Kampus Unand Limau Manis, Padang, West Sumatera, Indonesia 25163; e-mail: shintaindah@ft.unand.ac.id
}

discharge of domestic and municipal wastes, industrial effluents, urban runoff, agricultural runoff, and atmospheric deposition (Kannel et al., 2007; Suthar et al., 2009). Levels of metals in rivers varies spatially. Land management of the catchment area for agriculture, forestry, conservation, industry, and urban areas influence pollutant discharge including metal contaminants that enter the aquatic system from different sources (Johnes and Heathwaite, 1997). Therefore, it is necessary to conduct monitoring studies on metal contaminations of river water in order to safeguard public health and to protect valuable freshwater resources.

Previous investigations indicated that concentrations of $\mathrm{Cd}$, $\mathrm{Cr}$, and $\mathrm{Fe}$ in the surface water of the Batang Arau River were very high and exceeded the maximum permitted concentrations established by the WHO (2004) and U.S. EPA (2009) drinking water quality guidelines (Environmental Impact Management Agency of Padang City, 2013). The concentrations of Cd, Cr, and $\mathrm{Fe}$ in the upstream stretches of the river, as the background concentration, were $0.03 \mathrm{mg} / \mathrm{L}, 0.07 \mathrm{mg} / \mathrm{L}$, and $0.31 \mathrm{mg} / \mathrm{L}$, whereas, downstream values were $0.05 \mathrm{mg} / \mathrm{L}, 0.2 \mathrm{mg} / \mathrm{L}$, and 0.41 $\mathrm{mg} / \mathrm{L}$, respectively. The maximum permitted concentrations by WHO (2004) are $0.003 \mathrm{mg} / \mathrm{L}$ and $0.05 \mathrm{mg} / \mathrm{L}$ for Cd and Cr; and $0.40 \mathrm{mg} / \mathrm{L}$ for Fe by U.S. EPA (2009). There is a lack of information on spatial distribution of metals in the waters of the Batang Arau River. Understanding the spatial distribution of metals in the basin is indispensable in determining originating sources and transport processes of the contamination (Jiang et al., 2012).

Spatial analysis of pollutants is important to better understand how sources of risk, the receptors, and the exposure pathways are distributed in space (Delgado et al., 2010). In addition, spatial analysis should be conducted within a river basin in order to investigate the effects of various land use types on water quality. This is because the effects of spatial dimensions of land uses and their effect on water quality remain unclear. Management of water resources requires designing strategic sampling locations for an effective monitoring program and thus spatial analysis is needed.

Multivariate statistical techniques such as cluster analysis (CA) and principal component analysis/factor analysis (PCA/ 
FA) are widely used to characterize and evaluate surface water and freshwater quality. These analyses also served as an useful tool to demonstrate temporal and spatial variations in metal concentrations caused by natural and anthropogenic factors (Helard et al., 2012; Manoj and Padhy, 2014; Shrestha and Kazama, 2007; Singh et al., 2005). The application of these techniques allow for the identification of possible factors that influence water environment systems and has proven to give a better interpretation and understanding of water quality data, offering a valuable tool for the reliable management of water resources (Caccia et al., 2003; Reid and Spencer, 2009; Simeonov et al., 2003).

Cluster analysis technique performs reliable classification of surface waters within the monitoring network. All sampling stations grouped together represent some similar features and backgrounds and need not be sampled each time; only one representative site in each cluster may provide enough information about the water quality of all sites within the monitoring network. It reduces the number of sampling sites and, therefore, the cost of monitoring programs. Cluster analysis also provides a visual summary of intrarelationships among the water quality parameters and assists in better understanding of the controlling factors (Pejman et al., 2009). Therefore, cluster analysis can provide information about optimal sampling strategies and river monitoring network design (Manoj and Padhy, 2014). Principal component analysis/factor analysis (PCA/FA) expediently describes reasons for spatial and temporal variations. The role of PCA/FA is not limited to identifying all possible sources of pollution or the origin of water quality parameters. These statistical techniques can also recognize essential parameters which affect the chemistry of each spatial or seasonal group of surface water (Pejman et al., 2009; Zare et al., 2011). Moreover, PCA/FA discloses the most important parameters responsible for variation in the dataset and also identifies the origin of pollutants and all possible water pollution sources (Manoj and Padhy, 2014).

The objective of the present study is to explore the spatial variation of metals pollution in the Batang Arau River. Thus far, a monitoring program and some investigations related to metallic pollution in the Batang Arau River are limited in only reporting the concentration of metals, without any information about their spatial distributions. To address this, an analysis was conducted using multivariate statistical techniques to assess metals causing pollution in the river and to clarify the natural and/or anthropogenic sources of these metals. The results of this study provide a better interpretation of metallic pollution and help develop water management and conservation strategies, as well as the design of an effective future spatial monitoring network in the Batang Arau River basin.

\section{Methodology}

Study Area. The Batang Arau River is about $30.6 \mathrm{~km}$ long and originates from Mount Bolak and flows to the west. The river passes the districts of Lubuk Kilangan, Lubuk Begalung, and Padang Selatan. The length from upstream to downstream is approximately $19827 \mathrm{~km}$ with a catchment area of approximately $172 \mathrm{~km}^{2}$. In the upstream stretches of Batang Arau River, the residential human population is relatively rare and a small portion of land is used for agriculture. At this location, the river divides into three tributaries namely Sikayan River, Timbulan River, and Karang Putih River (Padang Statistic Center, 2009). However, intense urbanization occurs from midstream to downstream in the Batang Arau River, potentially causing water pollution.

Sample Sites. Surface water samples were collected from eight stations along the Batang Arau River at biweekly intervals between March and May 2014. The sampling stations were classified as one baseline station (S1) and seven impact stations (S2, S3, S4, S5, S6, S7, and S8). The baseline station is concerned with the natural and unpolluted state of the river basin that is located upstream of the river, and the impact stations are used for measuring the quantity of pollutant and extent of pollution because of human interference. Figure 1 shows the locations of the sampling stations. A detailed description of sampling stations is given in Table 1 .

Laboratory Analysis. Five sampling trips by grab method were carried out from March to May 2014. Water samples for metals analysis were collected in $1 \mathrm{~L}$ glass bottles and acidified with $65 \%$ concentrated nitric acid to $\mathrm{pH}$ less than 2 , in the field. Because the flow velocity of the river was in the range of 5 to 150 $\mathrm{m}^{3} / \mathrm{s}$, according to the Indonesian National Standard Sampling methods for surface water, water samples were taken from onethird and two-third across the river width and one-half of the river depth (National Standardization Agency of Indonesia, 2008). Temperature, $\mathrm{pH}$, and dissolved oxygen were determined in the field. All sample bottles were placed in cooler boxes with ice at approximately $4{ }^{\circ} \mathrm{C}$. Analysis of water samples was carried out within two weeks. The water samples were filtered using $0.45 \mu \mathrm{m}$ glass fiber filters (Advantec, Japan) before analysis. Acidified samples of $100 \mathrm{ml}$ were added with $1 \%$ of $70 \%$ concentrated $\mathrm{HNO}_{3}(1.5 \mathrm{~mL})$ in a $100 \mathrm{~mL}$ volumetric flask (APHA, 1998). Lastly, the solution was analyzed for Cd, Co, Cr, $\mathrm{Fe}, \mathrm{Mn}$, and $\mathrm{Pb}$ using an atomic absorption spectrophotometer (AAS) (Rayleigh WFX 320, China) after calibration with respective standard solutions of $0 \mathrm{mg} / \mathrm{L}, 0.5 \mathrm{mg} / \mathrm{L}, 1 \mathrm{mg} / \mathrm{L}, 2$ $\mathrm{mg} / \mathrm{L}$, and $3 \mathrm{mg} / \mathrm{L}$. The AAS has a detection limit of $\leq 0.006$ $\mathrm{mg} / \mathrm{L}$ with the D2 lamp as background correction. Each sample was analyzed in triplicate and average readings were automatically determined.

Statistical Analysis. One-way analysis of variance (ANOVA) was performed to examine significant spatial variations in metals. Hierarchical agglomerative cluster analysis was performed on the normalized data set to group the similar sampling sites and variables, using Ward's method with Euclidean distances as a measure of similarity (Varol and Şen, 2009, 2012). Principle component analysis/factor analysis (PCA/FA) was employed to identify possible source types. Factor analysis was conducted after principal component analysis. Principal component analysis of the normalized variables (data set) was performed to extract significant principal components and to further reduce the contribution of variables with minor significance; these principal components were then subjected to 


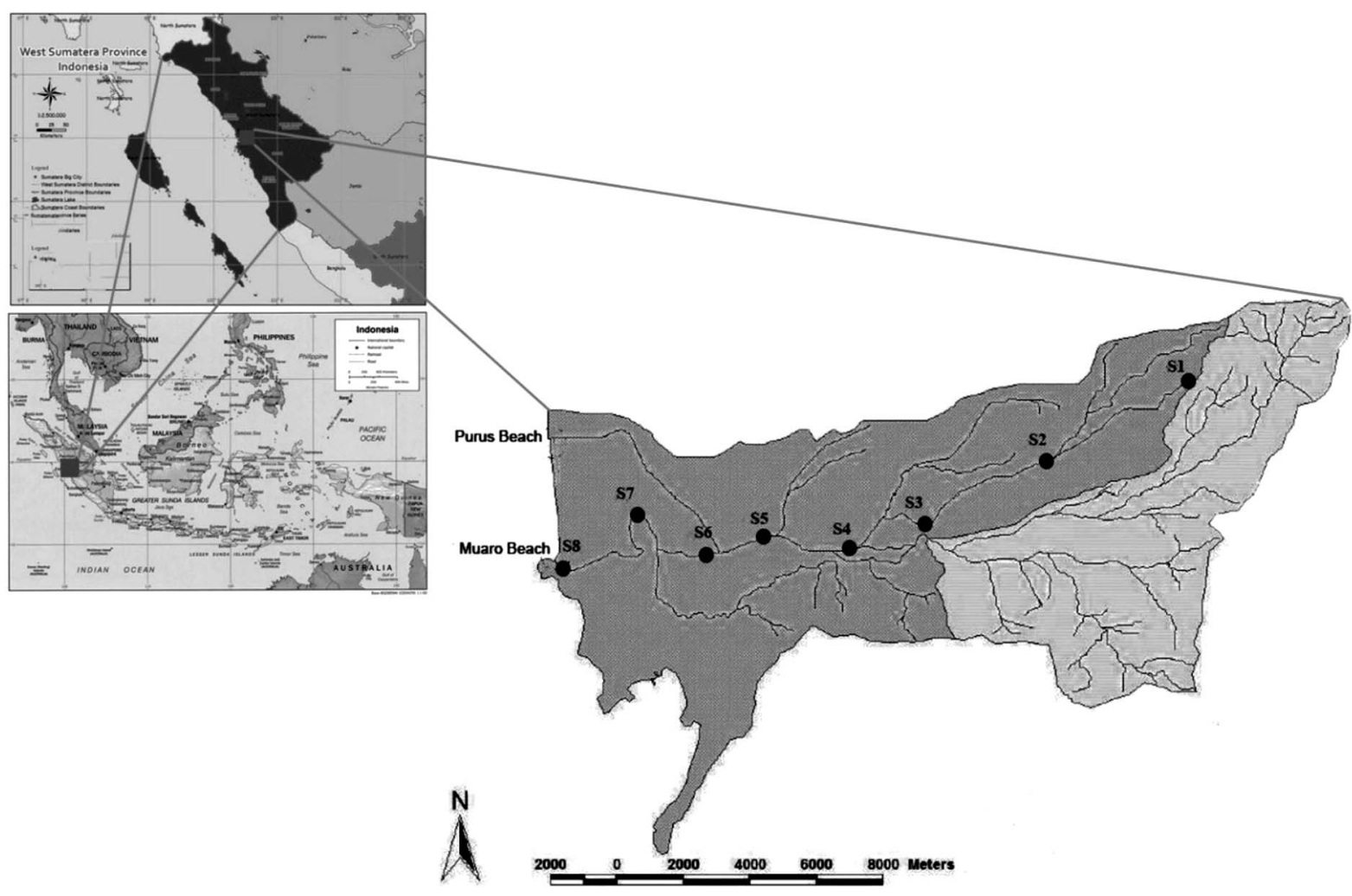

Figure 1-Map showing sampling stations on the Batang Arau River.

varimax rotation (raw) to generate varifactors (Varol et al., 2013). Kaiser-Meyer-Olkin (KMO) and Bartlett's sphericity tests were performed to examine the suitability of the data for PCA/ FA (Varol and Şen, 2009). Spearman's rank correlations were used to identify the relationship among metals. Statistical analysis was performed using SPSS version 20.0.

\section{Results and Discussion}

Spatial Variations of Metals in the Batang Arau River. Spatial variation of metals including $\mathrm{Cd}, \mathrm{Co}, \mathrm{Cr}, \mathrm{Fe}, \mathrm{Mn}$, and $\mathrm{Pb}$ in the Batang Arau River are illustrated by box-whisker plots (Figure 2), whereas overall means, standard deviations, and minimum and maximum concentrations of metals at the eight

Table 1-Description of eight sampling stations.

\begin{tabular}{|c|c|c|c|c|c|}
\hline Stations & Latitude & Longitude & $\begin{array}{c}\text { Elevation, } \\
\text { m.a.s.l. * (m) }\end{array}$ & $\begin{array}{l}\text { Distance } \\
\text { (from S1), } \\
\quad(\mathrm{km})\end{array}$ & Description \\
\hline S1 & $0^{\circ} 56^{\prime} 49.9^{\prime \prime}$ & $100^{\circ} 30^{\prime} 31.5^{\prime \prime}$ & 229 & 0 & Upstream of the Batang Arau River which is located in a forested area. \\
\hline S2 & $0^{\circ} 57^{\prime} 30.4^{\prime \prime}$ & $100^{\circ} 27^{\prime} 08.0^{\prime \prime}$ & 124 & 4.2 & $\begin{array}{l}\text { Located on a drain which is carrying wastewater from a limestone mill } \\
\text { and agricultural activities. }\end{array}$ \\
\hline S3 & $0^{\circ} 57^{\prime} 39.7^{\prime \prime}$ & $100^{\circ} 25^{\prime} 29.7^{\prime \prime}$ & 72 & 10.1 & $\begin{array}{l}\text { Received wastewater from households and commercial activities. The } \\
\text { water load increases as a result of the merging of two nearby } \\
\text { tributaries in this area. }\end{array}$ \\
\hline S4 & $0^{\circ} 57^{\prime} 40.8^{\prime \prime}$ & $100^{\circ} 24^{\prime} 02.3^{\prime \prime}$ & 18 & 13.8 & The river has passed through agricultural and industrial areas. \\
\hline S5 & $0^{\circ} 57^{\prime} 43.3^{\prime \prime}$ & $100^{\circ} 22^{\prime} 54.1^{\prime \prime}$ & 7 & 16.7 & $\begin{array}{l}\text { The streams have received wastewater from rubber industry and the } \\
\text { discharge of the river water has been reduced as a result of } \\
\text { diverting to the nearby flood control channel. }\end{array}$ \\
\hline S6 & $0^{\circ} 57^{\prime} 26.8^{\prime \prime}$ & $100^{\circ} 22^{\prime} 41.1^{\prime \prime}$ & 6 & 17.6 & $\begin{array}{l}\text { Located after the streams couple with the secondary drainage } \\
\text { channels, called Batang Jirak, which receive wastewater from the } \\
\text { domestic and commercial areas. }\end{array}$ \\
\hline S7 & $0^{\circ} 57^{\prime} 41.4^{\prime \prime}$ & $100^{\circ} 22^{\prime} 28.4^{\prime \prime}$ & 3 & 18.9 & $\begin{array}{l}\text { The stream couples with the channel of Jati Drain that receives } \\
\text { wastewater from domestic and commercial activities. }\end{array}$ \\
\hline S8 & $0^{\circ} 57^{\prime} 44.8^{\prime \prime}$ & $100^{\circ} 21^{\prime} 51.5^{\prime \prime}$ & 1 & 19.9 & Downstream of the river; all pollutants along the river accumulated. \\
\hline
\end{tabular}

* $\mathrm{m}$ a.s.l. : meters above sea level 

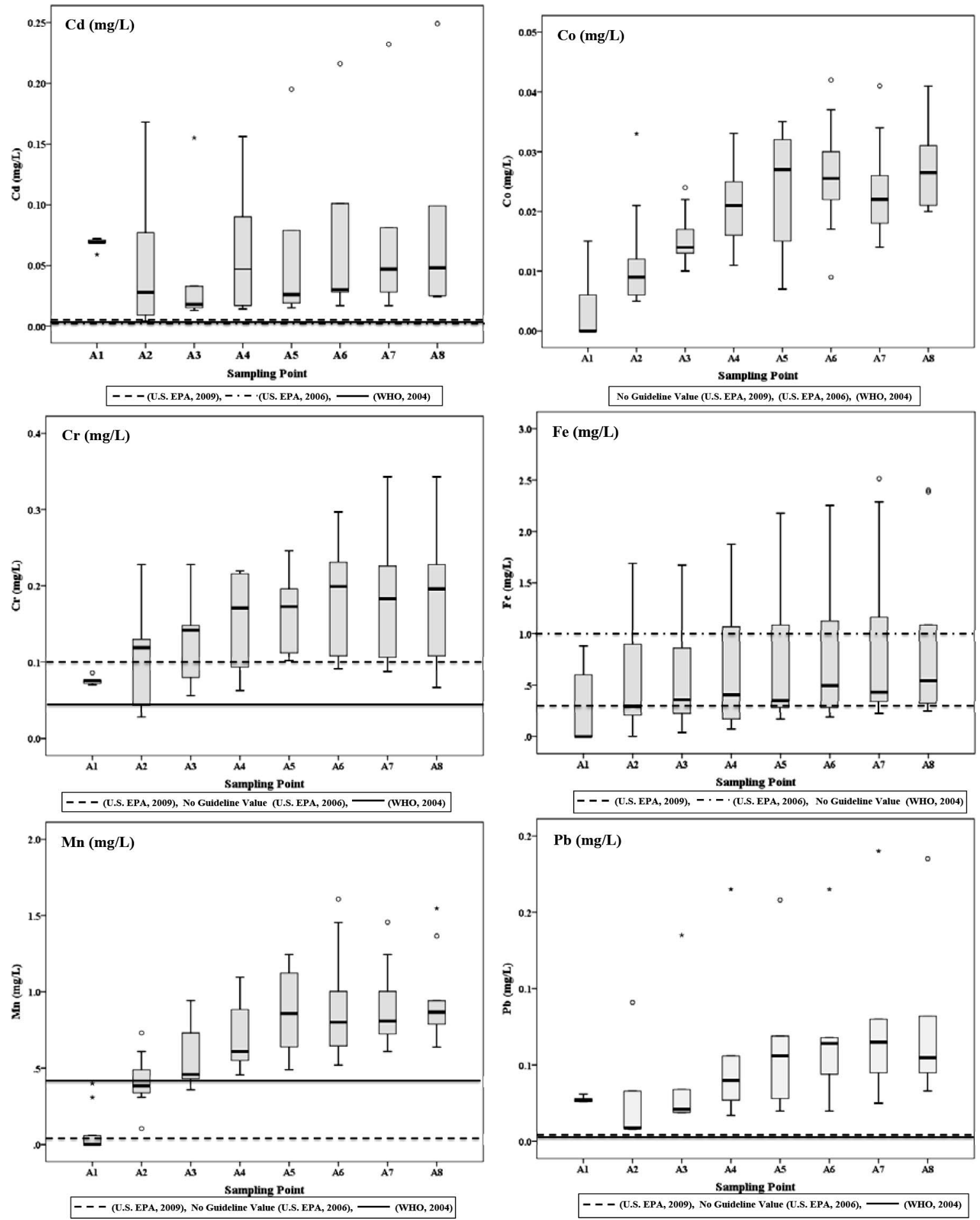

Figure 2-Spatial variations of $\mathrm{Cd}, \mathrm{Co}, \mathrm{Cr}$, $\mathrm{Fe}, \mathrm{Mn}$, and $\mathrm{Pb}$ in the Batang Arau River.

sampling points are summarized in Table 2. The concentrations of metals including $\mathrm{Cd}, \mathrm{Co}, \mathrm{Cr}, \mathrm{Fe}, \mathrm{Mn}$, and $\mathrm{Pb}$ were in the range of 0.047 to $0.089 \mathrm{mg} / \mathrm{L}, 0.008$ to $0.028 \mathrm{mg} / \mathrm{L}, 0.060$ to 0.189 $\mathrm{mg} / \mathrm{L}, 0.563$ to $0.925 \mathrm{mg} / \mathrm{L}, 0.205$ to $0.939 \mathrm{mg} / \mathrm{L}$, and 0.025 to $0.081 \mathrm{mg} / \mathrm{L}$, respectively.

Typically, all the metals have similar spatial distribution patterns, with an increasing trend in concentration from upstream to downstream in the Batang Arau River. For instance, the mean concentration of $\mathrm{Cr}$ increased from $0.060 \pm 0.018 \mathrm{mg} /$ $\mathrm{L}$ upstream to $0.188 \pm 0.108 \mathrm{mg} / \mathrm{L}$ downstream. The upstream area represents a natural and unpolluted river reflecting the natural background concentrations of metals. In this case, S1, located in the upstream stretches of the Batang Arau River and the reference stream for the other stations, is located in a 
Table 2-Overall means, standard deviations, and minimum and maximum concentrations of metals at the eight sampling points on the Batang Arau River $(n=5)$.

\begin{tabular}{|c|c|c|c|c|c|c|c|c|c|}
\hline \multirow[b]{2}{*}{ Stations } & \multicolumn{6}{|c|}{ Concentration (mg/L) } & \multicolumn{3}{|c|}{ Environmental Parameters } \\
\hline & Cd & Co & $\mathrm{Cr}$ & $\mathrm{Fe}$ & Mn & $\mathrm{Pb}$ & $\mathrm{T}\left({ }^{\circ} \mathrm{C}\right)$ & $\mathrm{pH}$ & $\mathrm{DO}$ (mg/L) \\
\hline \multicolumn{10}{|l|}{$\overline{S 1}$} \\
\hline Mean & $0.048^{a}$ & $0.008^{a}$ & $0.060^{a}$ & $0.704^{a}$ & $0.205^{a}$ & $0.025^{a}$ & 25.8 & 8.4 & 8.5 \\
\hline Std. Dev. & 0.014 & 0.006 & 0.018 & 0.179 & 0.175 & 0.010 & 0.4 & 0.4 & 0.3 \\
\hline Min & 0.031 & 0.001 & 0.042 & 0.507 & 0.057 & 0.017 & 25.2 & 8.0 & 8.0 \\
\hline Max & 0.069 & 0.015 & 0.083 & 0.882 & 0.399 & 0.043 & 26.2 & 8.9 & 8.9 \\
\hline \multicolumn{10}{|l|}{ S2 } \\
\hline Mean & $0.057^{a}$ & $0.012^{a}$ & $0.110^{a}$ & $0.563^{a}$ & $0.420^{a}$ & $0.030^{a}$ & 28.6 & 8.7 & 7.2 \\
\hline Std. Dev. & 0.069 & 0.009 & 0.080 & 0.562 & 0.173 & 0.036 & 1.8 & 0.5 & 0.7 \\
\hline Min & 0.004 & 0.005 & 0.028 & 0.000 & 0.105 & 0.008 & 26.4 & 8.1 & 6.4 \\
\hline Max & 0.168 & 0.033 & 0.228 & 1.689 & 0.731 & 0.091 & 31.2 & 9.1 & 8.3 \\
\hline \multicolumn{10}{|l|}{ S3 } \\
\hline Mean & $0.047^{a}$ & $0.015^{a}$ & $0.131^{a}$ & $0.619^{a}$ & $0.576^{a b}$ & $0.046^{a}$ & 30.7 & 8.7 & 7.4 \\
\hline Std. Dev. & 0.061 & 0.004 & 0.067 & 0.596 & 0.215 & 0.050 & 2.5 & 0.9 & 0.9 \\
\hline Min & 0.013 & 0.010 & 0.056 & 0.038 & 0.359 & 0.019 & 28.1 & 7.8 & 6.1 \\
\hline Max & 0.155 & 0.024 & 0.228 & 1.670 & 0.943 & 0.135 & 34.7 & 9.6 & 8.2 \\
\hline \multicolumn{10}{|l|}{ S4 } \\
\hline Mean & $0.065^{a}$ & $0.021^{a b}$ & $0.153^{a}$ & $0.732^{a}$ & $0.704^{a b}$ & $0.061^{a}$ & 30.6 & 7.9 & 6.2 \\
\hline Std. Dev. & 0.059 & 0.007 & 0.072 & 0.677 & 0.233 & 0.060 & 1.7 & 0.4 & 1.8 \\
\hline Min & 0.014 & 0.011 & 0.063 & 0.075 & 0.455 & 0.017 & 29.3 & 7.4 & 3.3 \\
\hline Max & 0.156 & 0.033 & 0.220 & 1.876 & 1.094 & 0.165 & 33.4 & 8.5 & 7.9 \\
\hline \multicolumn{10}{|l|}{ S5 } \\
\hline Mean & $0.067^{a}$ & $0.023^{a b}$ & $0.166^{a}$ & $0.805^{a}$ & $0.879^{a b}$ & $0.066^{a}$ & 30.5 & 7.7 & 6.9 \\
\hline Std. Dev. & 0.076 & 0.010 & 0.060 & 0.781 & 0.261 & 0.055 & 1.8 & 0.6 & 1.1 \\
\hline Min & 0.015 & 0.007 & 0.102 & 0.169 & 0.489 & 0.020 & 29.2 & 7.1 & 5.2 \\
\hline Max & 0.195 & 0.035 & 0.246 & 2.176 & 1.245 & 0.158 & 33.7 & 8.2 & 7.9 \\
\hline \multicolumn{10}{|l|}{ S6 } \\
\hline Mean & $0.078^{a}$ & $0.026 a b$ & $0.185^{a}$ & $0.871^{a}$ & $0.906^{a b}$ & $0.072^{a}$ & 30.5 & 7.6 & 7.2 \\
\hline Std. Dev. & 0.084 & 0.009 & 0.086 & 0.793 & 0.370 & 0.055 & 1.7 & 0.4 & 0.3 \\
\hline Min & 0.017 & 0.009 & 0.091 & 0.188 & 0.520 & 0.020 & 29.6 & 7.2 & 6.9 \\
\hline Max & 0.216 & 0.042 & 0.297 & 2.251 & 1.607 & 0.165 & 33.6 & 8.1 & 7.6 \\
\hline \multicolumn{10}{|l|}{ S7 } \\
\hline Mean & $0.081^{a}$ & $0.024^{a b}$ & $0.189^{a}$ & $0.921^{a}$ & $0.890 \mathrm{ab}$ & $0.081^{a}$ & 30.4 & 7.6 & 7.0 \\
\hline Std. Dev. & 0.088 & 0.009 & 0.103 & 0.852 & 0.271 & 0.064 & 1.1 & 0.4 & 0.5 \\
\hline Min & 0.017 & 0.014 & 0.088 & 0.225 & 0.610 & 0.025 & 29.7 & 7.2 & 6.6 \\
\hline Max & 0.232 & 0.041 & 0.343 & 2.514 & 1.456 & 0.190 & 32.3 & 8.2 & 7.9 \\
\hline \multicolumn{10}{|l|}{ S8 } \\
\hline Mean & $0.089^{a}$ & $0.028^{a b}$ & $0.188^{a}$ & $0.925^{a}$ & $0.939^{a b}$ & $0.080^{a}$ & 30.4 & 7.5 & 6.7 \\
\hline Std. Dev. & 0.094 & 0.007 & 0.108 & 0.825 & 0.291 & 0.061 & 1.1 & 0.6 & 0.9 \\
\hline Min & 0.024 & 0.020 & 0.067 & 0.244 & 0.640 & 0.033 & 29.5 & 6.9 & 5.5 \\
\hline Max & 0.249 & 0.041 & 0.343 & 2.402 & 1.547 & 0.185 & 32.4 & 8.1 & 8.0 \\
\hline \multicolumn{10}{|l|}{ Overall } \\
\hline Mean & 0.067 & 0.020 & 0.148 & 0.767 & 0.690 & 0.058 & 29.7 & 8.0 & 7.1 \\
\hline Std. Dev. & 0.015 & 0.007 & 0.046 & 0.136 & 0.269 & 0.022 & 1.7 & 0.5 & 0.7 \\
\hline Min & 0.047 & 0.008 & 0.060 & 0.563 & 0.205 & 0.025 & 25.8 & 7.5 & 6.2 \\
\hline Max & 0.089 & 0.028 & 0.189 & 0.925 & 0.939 & 0.081 & 30.7 & 8.7 & 8.5 \\
\hline \multicolumn{10}{|c|}{ Water quality guidelines } \\
\hline \multicolumn{10}{|c|}{ Drinking water quality } \\
\hline $\mathrm{WHO}(2004)$ & 0.003 & $\mathrm{NGV}^{* *}$ & 0.05 & $N G V *$ * & 0.4 & 0.01 & & & \\
\hline U.S. EPA (2009) & 0.005 & & 0.1 & 0.3 & 0.05 & 0.015 & & & \\
\hline \multicolumn{10}{|c|}{ Acute values for protection of freshwater aquatic life } \\
\hline U.S. EPA (2006) & 0.002 & $\mathrm{NGV}^{* *}$ & 0.016 & 1 & $\mathrm{NGV}^{* *}$ & 0.065 & & & \\
\hline
\end{tabular}

* Means within a column followed by same letters are not significantly different at $5 \%$ level

** NGV: No guideline value

forested area and there is no influence from human activities on water quality in this area. Usually, in unaffected environments, the concentration of most of the metals in rivers is very low and mostly derived from the weathering of rock and soil (Varol and
Şen, 2012). Therefore, the concentrations of metals at S1 station are relatively lower than at the other stations. The increase in metal concentrations downstream may be attributable to anthropogenic influences such as domestic, agricultural, and 


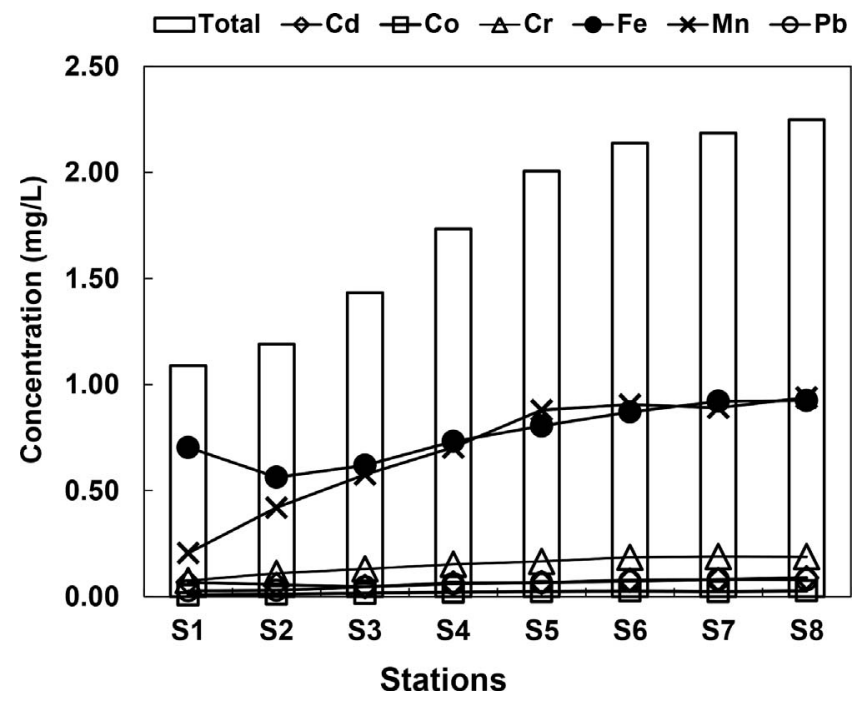

Figure 3-Total concentrations of six metals at the different sampling stations on the Batang Arau River.

industrial activities along the Batang Arau River, as the concentration of all metals at all stations had much higher average values than those in water samples from the reference stream, S1. This implies that increased metal concentrations most likely originated from anthropogenic activities.

As presented at Table 1, there are some anthropogenic sources along the Batang Arau River. Station 2 (S2) is about $4.2 \mathrm{~km}$ from the reference stream (S1), located on a drain which carries wastewater from a limestone mill as well as agricultural activities; paddy fields are located nearby. About $5.9 \mathrm{~km}$ from S2, there is S3 station. At this station, the Batang Arau River receives wastewater from households and commercial activities. In addition, there is sand mining activity and an increase in water load because of the merging of two tributaries near this area (Lubuk Paraku and Batang Idas). Next to S3, there is S4 station, where the river passes through agricultural and industrial areas (industrial wastewater comes from the rubber industry and palm oil processing industry). At S5 station, about $16.7 \mathrm{~km}$ from $\mathrm{S} 1$, the river receives wastewater from the rubber industry and the discharge of river water has been reduced as a result of diverting to the nearby flood control channel. About 1 $\mathrm{km}$ from S5, and $17.6 \mathrm{~km}$ from S1, there is $\mathrm{S} 6$ station. This station is located after the river couples with a secondary drainage channel, called Batang Jirak, which receives wastewater from domestic and commercial areas such as the public market and auto services. Similarly to S6, at S7 station (located about $1.3 \mathrm{~km}$ from S6) the river couples with the Jati Drain channel that receives wastewater from domestic and commercial activities including restaurants, a hospital and a hotel. Finally, the last station is S8 station, the outlet of the Batang Arau River before entering the sea. At this station, all pollutants which come from domestic and industrial, as well as agricultural wastewater, along the river have accumulated, because this area is furthest downstream in the Batang Arau River, near the estuary that merges with the ocean.

However, although there were different kinds of human activities along the river, spatial distribution of metals indicated that the concentrations of $\mathrm{Cd}, \mathrm{Cr}, \mathrm{Fe}$, and $\mathrm{Pb}$ did not show significant spatial variability at the eight sampling points $(p<$ $0.05)$, reflected by the ANOVA results presented in Table 2. This may be explained by the lack of anthropogenic sources along the river to change the spatial distribution of metals. On the other hand, significant spatial variabilities were found in the concentration of Co and Mn along the Batang Arau River. The concentration of Co increased significantly at S4, S5, S6, S7, and S8, compared to those upstream S1, S2, and S3. For Mn, significant differences in concentration were observed from $\mathrm{S} 3$ to S8 stations. These findings reveal that anthropogenic sources and different land uses along the Batang Arau River may lead to significant variability in the spatial distribution of Co and $\mathrm{Mn}$ concentrations in the river. From S4 to S8, wastewater from industrial, agricultural, and domestic sources are released into the river resulting in these significant differences in metal concentrations. This fact is supported by the flow rate data observed along the river, as shown in Table 1 . At S4, flow rate increased, because the river received wastewater from household, agricultural, and industrial activities. The flow rate was reduced at S5 as a result of diverting to the nearby flood control channel. Furthermore, an increase inflow rate was observed from S6 to S8, reflecting the discharge of wastewater from various anthropogenic sources along the river.

The relative abundance of metals in the Batang Arau River was, in decreasing order, $\mathrm{Fe}>\mathrm{Mn}>\mathrm{Cr}>\mathrm{Cd}>\mathrm{Pb}>\mathrm{Co}$, and the mean concentrations of metals were $0.767 \pm 0.136 \mathrm{mg} / \mathrm{L}$ $(\mathrm{Fe}), 0.690 \pm 0.269 \mathrm{mg} / \mathrm{L}(\mathrm{Mn}), 0.148 \pm 0.046 \mathrm{mg} / \mathrm{L}(\mathrm{Cr}), 0.067$ $\pm 0.015 \mathrm{mg} / \mathrm{L}(\mathrm{Cd}), 0.058 \pm 0.022 \mathrm{mg} / \mathrm{L}(\mathrm{Pb})$, and $0.020 \pm 0.007$ $\mathrm{mg} / \mathrm{L}(\mathrm{Co})$. It is well known that $\mathrm{Fe}$ is one of the most abundant metals within the earth's crust, therefore, it is ubiquitous in all freshwater environments and often reaches significantly higher concentrations in water and sediments than other trace metals (Forstner and Wittman, 1979). In addition to natural occurrence from the product of weathered rocks and soil within watersheds, another source of $\mathrm{Fe}$ in water is from anthropogenic activities, including municipal wastewater discharges, sewage sludge, mining and mineral processing, and industrial and agricultural wastewater (TRI91, 1993; Xing and Liu, 2011).

The total concentrations of six metals in the sampled river water had an average of $1.749 \mathrm{mg} / \mathrm{L}$, followed by S8 $(2.249 \mathrm{mg}$ / L), S7 (2.186 mg/L), S6 (2.139 mg/L), S5 (2.006 mg/L), S4 (1.735 $\mathrm{mg} / \mathrm{L}), \mathrm{S} 3(1.433 \mathrm{mg} / \mathrm{L}), \mathrm{S} 2$ (1.191 mg/L), and S1 (1.050 mg/L), as shown in Figure 3. The highest total concentration of all metals was found at S8 perhaps because of the accumulation of pollutants released from anthropogenic activities, such as domestic, industrial, commercial, and agricultural sources, at this point. S8 station is located in the downstream stretches of the Batang Arau River, near the estuary, before the river enters the sea. The lowest total concentration was observed at S1, the upstream stretches of the river not affected by anthropogenic activities, reflecting the natural background concentration of 


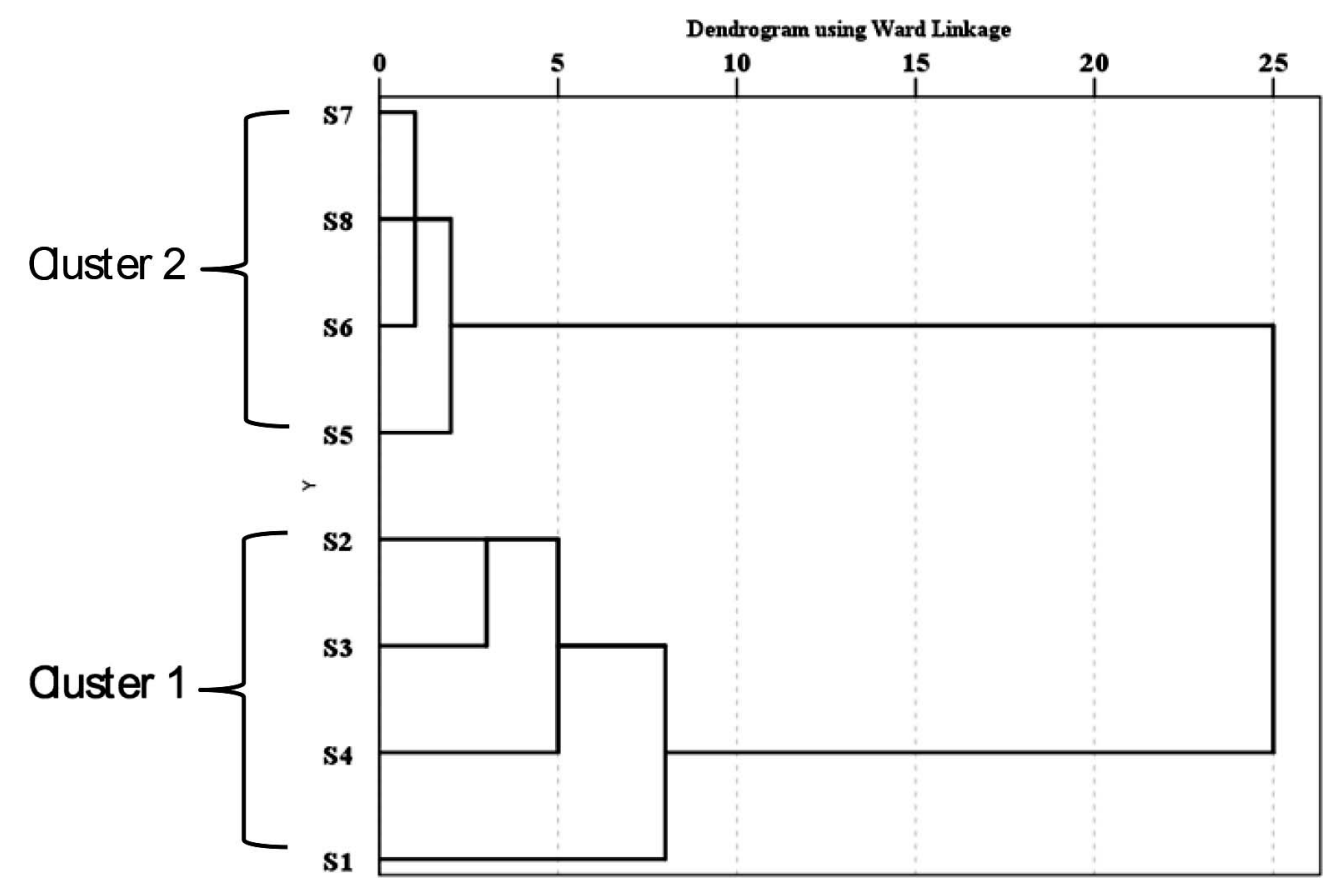

Figure 4-Dendrogram showing clustering of sampling stations on the Batang Arau River.

metals in the Batang Arau River. Figure 3 also presents the variation of each metal along the sampling stations. It is observed that the increasing concentrations of metals downstream were not at a uniform rate.

Furthermore, metal concentrations were compared with water quality guidelines (or standards) for drinking water (U.S. EPA, 2009; WHO, 2004) and the protection of freshwater aquatic life (U.S. EPA, 2006), as also shown in Figure 2. Typically, the mean concentrations of all metals studied were higher than the maximum permitted concentrations established by WHO and U.S. EPA drinking water quality guidelines (Table 2). Regarding spatial concentrations of metals and guidelines; $\mathrm{Cd}, \mathrm{Fe}$, and $\mathrm{Pb}$ concentrations at all stations exceeded WHO and U.S. EPA drinking water limits. The concentration of $\mathrm{Cd}$ was in the range of 0.048 to0.089 mg/L, whereas the WHO and U.S. EPA drinking limits are $0.003 \mathrm{mg} / \mathrm{L}$ and $0.005 \mathrm{mg} / \mathrm{L}$. For Cr, its concentration along the river was in the range of 0.060 to 0.188 $\mathrm{mg} / \mathrm{L}$, exceeding the maximum permitted concentration in the drinking water guidelines $(0.05 \mathrm{mg} / \mathrm{L}$ for $\mathrm{WHO}$ and $0.1 \mathrm{mg} / \mathrm{L}$ for U.S. EPA). The concentration of $\mathrm{Fe}$ and $\mathrm{Pb}$ at all stations was in the range of 0.704 to $0.925 \mathrm{mg} / \mathrm{L}$ and 0.025 to $0.080 \mathrm{mg} / \mathrm{L}$, exceeding the drinking water limits of the WHO $(0.01 \mathrm{mg} / \mathrm{L}$ for $\mathrm{Pb})$ and U.S. EPA $(0.3 \mathrm{mg} / \mathrm{L}$ for Fe and $0.015 \mathrm{mg} / \mathrm{L}$ for $\mathrm{Pb})$. For $\mathrm{Cr}$ and $\mathrm{Mn}$, their concentrations at S1, located in the upstream stretches of the Batang Arau River, were still below the U.S. EPA and WHO drinking water limits, respectively. However their concentrations increased and violated the permissible limit of the WHO and U.S. EPA guidelines for drinking water at the next stations (from S2 to S8). It was also determined that the mean concentration of all metals exceeded the maximum permitted concentrations for the protection of aquatic life (U.S. EPA, 2006), except $\mathrm{Fe}$ and $\mathrm{Pb}$. The mean concentrations of $\mathrm{Fe}$ and $\mathrm{Pb}$ were lower than the maximum permitted concentration for the protection of aquatic life, whereas their maximum concentrations from S2 until S8 station were higher than the maximum permitted concentration (Table 2). Hence, to protect aquatic life, much greater attention should be paid to all metals.

Multivariate Statistical Analyses. Cluster analysis was utilized to group the similar sampling sites (spatial variability) and to identify specific areas of contamination. Hierarchical clustering analysis (HCA) is the most common approach, which presents perceptive similarity between any one sample and the entire data set. In this study, hierarchical agglomerative cluster analysis was performed on the normalized data set using Ward's method, with Euclidean distances as a measure of similarity. Hierarchical clustering analysis (HCA) is usually demonstrated by a dendrogram (tree diagram) which presents a visual outline of the clustering processes, presenting a picture of the groups and their proximity, with a dramatic reduction in the dimensionality of the original data. Furthermore, KMO and Bartlett's sphericity tests were applied to examine the validity of PCA/FA in identifying possible source types, and extract significant principal components (Varol et al., 2013).

Spatial Similarity and Site Grouping. A dendrogram derived from HCA shows that the eight sampling stations on the river are grouped into two statistically significant clusters (Figure 4). Cluster 1 consists of stations S1, S2, S3, and S4; whereas cluster 2 consists of stations S5, S6, S7, and S8. The cluster classifications change with significant level because the sites, or stations, in the groups have similar characteristic features that are affected by similar sources. Compared to their average data and information in clusters with drinking water guidelines (Table 2), it could be concluded that clusters 1 and 2 corresponded to relatively moderate, and highly polluted 
Table 3-Varimax rotated factor loadings.

\begin{tabular}{lccc}
\hline & \multicolumn{3}{c}{ Initial Eigenvalues } \\
\cline { 2 - 4 } Component & Total & \% of Variance & Cumulative \% \\
\hline 1 & 3.259 & 54.316 & 54.316 \\
2 & 1.216 & 20.265 & 74.581 \\
3 & 1.005 & 16.743 & 91.324 \\
4 & 0.279 & 4.654 & 95.978 \\
5 & 0.224 & 3.736 & 99.715 \\
6 & 0.017 & 0.285 & 100 \\
& & & \\
& & Component & \\
Element & VF1 & VF2 & VF3 \\
\hline Fe & $\mathbf{0 . 8 7 5}$ & 0.392 & -0.174 \\
$\mathrm{Mn}$ & -0.028 & 0.114 & $\mathbf{0 . 9 6 4}$ \\
$\mathrm{Co}$ & $\mathbf{0 . 8 3 9}$ & 0.013 & 0.406 \\
$\mathrm{~Pb}$ & 0.104 & $\mathbf{0 . 9 3 2}$ & 0.136 \\
$\mathrm{Cd}$ & $\mathbf{0 . 9 1 6}$ & 0.299 & -0.16 \\
$\mathrm{Cr}$ & 0.39 & $\mathbf{0 . 8 4 4}$ & 0.018 \\
\hline
\end{tabular}

regions, respectively. Cluster 1 is situated upstream of the middle course of the Batang Arau River. The upstream area (S1) is located in a forested area and there is no influence of human activities on water quality in this area, reflecting the natural background concentration of metals, thus, their concentrations were relatively lower. Next to S1, at stations S2, S3, and S4, an increase in metal concentrations was observed, indicating the discharge of pollutants from anthropogenic sources such as domestic, agricultural, and industrial wastewater. Cluster 2 corresponded to relatively high pollution stations. The stations included in this cluster are located towards the downstream end of the Batang Arau River, where all pollutants from human activities along the river have accumulated, so that the concentration of metals were higher than in the previous stations. The cluster analysis has provided a useful classification of the surface watercourses in the study area, and could be used to design an optimal spatial monitoring network with lower costs (Simeonov et al., 2003; Singh et al., 2005). Based on our results, the number of monitoring stations could be reduced and chosen only from cluster 1 and 2. This result suggests that for the rapid assessment of water quality, only one station in each cluster would be sufficient. This could serve as a good spatial assessment of the water quality of the whole group.

Source Identification. Kaiser-Meyer-Olkin (KMO) and Bartlett's results were 0.661 and $180(\mathrm{df}=15, p<0.001)$, respectively, indicating that PCA/FA would be effective in reducing dimensionality of the data set. In this study, three varifactors with eigenvalues $>1$, explaining about $91.324 \%$ of the total variance in the water quality data set, were obtained through factor analysis performed on the principal components. The corresponding varifactors, variable loadings and explained variance are given in Table 3. Varifactor coefficients having a correlation greater than 0.70 were considered significant (strong). Varifactor 1 (VF1), which explained $54.316 \%$ of the total variance, had strong positive loadings $(>0.70)$ on $\mathrm{Cd}, \mathrm{Co}$, and Fe. VF2, which accounted for $20.265 \%$ of the total variance, had strong positive loadings on $\mathrm{Cr}$ and $\mathrm{Pb}$. VF3 (16.743\% of the total variance) had strong positive loadings on $\mathrm{Mn}$.

The first cluster of elements (Cd, Co, and Fe) significantly correlated with each other $(r=0.600, p<0.01)$, as shown in Table 4. Moreover, Cd and Fe did not show significant spatial variations, reflecting no significant anthropogenic source along the river, therefore, these metals may originate from a natural source. However, Co had significant spatial variation at the station in the middle course of the Batang Arau River along to the downstream stretches of the river (S4, S5, S6, S7, and S8), indicating the influence of anthropogenic activities and different land uses along the river (Table 2). Thus, VF 1 can be attributable to mixed sources of natural and anthropogenic origin. The second cluster of elements $(\mathrm{Cr}$ and $\mathrm{Pb})$ showed significant correlations with each other $(r=0.742, p<0.01)$. This implies that $\mathrm{Cr}$ and $\mathrm{Pb}$ are most likely derived from a common source and are also moving together. In addition, these metals had no significant spatial variations, suggesting there were no significant anthropogenic sources of these metals along the river to change their spatial distributions (Table 2). Hence, VF2 can be attributed to natural sources. The third group of elements $(\mathrm{Mn})$ did not show significant correlation with any of the other metals. Manganese had relatively high concentrations in the Batang Arau River and significant spatial variation from S3 to S8 (Table 2), reflecting the differences in anthropogenic activities along the river. Therefore, VF3 can be attributed to anthropogenic sources.

\section{Conclusions}

The results indicate that, typically, all metals studied have a similar spatial distribution pattern, with an increasing trend in concentration from upstream to downstream in the Batang Arau River, reflecting the influences of natural and anthropogenic

Table 4-Spearman's rank correlation coefficients of metals in the Batang Arau River.

\begin{tabular}{|c|c|c|c|c|c|c|}
\hline & $\mathrm{Fe}$ & $\mathrm{Mn}$ & Co & $\mathrm{Pb}$ & $\mathrm{Cd}$ & $\mathrm{Cr}$ \\
\hline $\begin{array}{l}\mathrm{Fe} \\
\mathrm{Mn}\end{array}$ & $\begin{array}{r}1.000 \\
-0.103\end{array}$ & 1.000 & & & & \\
\hline Co & $0.600^{* *}$ & 0.284 & 1.000 & & & \\
\hline $\mathrm{Pb}$ & $0.427^{* *}$ & 0.198 & 0.205 & 1.000 & & \\
\hline $\mathrm{Cd}$ & $0.977^{* *}$ & -0.103 & $0.641^{* *}$ & $0.354^{*}$ & 1.000 & \\
\hline $\mathrm{Cr}$ & $0.636^{* *}$ & 0.101 & $0.355^{*}$ & $0.742^{* *}$ & $0.579^{* *}$ & 1.000 \\
\hline
\end{tabular}

** Correlation is significant at the 0.01 level (2-tailed).

* Correlation is significant at the 0.05 level (2-tailed). 
sources along the river. Spatial distribution of metals reveal that the concentrations of $\mathrm{Cd}, \mathrm{Cr}, \mathrm{Fe}$, and $\mathrm{Pb}$ did not show significant variability at the eight sampling points $(p<0.05)$, indicating there were no significant anthropogenic sources of these metals along the river to change their spatial distributions. However, significant spatial variabilities were found in the concentration of Co and Mn along the Batang Arau River. This implies that there were anthropogenic sources and different land uses along the Batang Arau River. The mean concentrations of all metals studied were higher than the maximum permitted concentrations established by the WHO (2004) and U.S. EPA (2009) drinking water quality guidelines, suggesting that all metals studied could be potential pollutants in the Batang Arau River. In addition, attention should be paid to all metals studied, as the mean concentration of all metals exceeded the maximum permitted concentrations for the protection of aquatic life (U.S EPA, 2006), except for the mean concentration of Fe and Pb.

Cluster analysis classified all the sampling sites into two main groups of spatial similarities. Based on these results, for the rapid assessment of water quality, the number of monitoring stations could be reduced and only one station chosen from cluster 1 and 2. It would reduce the number of sampling sites in turn, reducing the cost of the water monitoring program for the Batang Arau River. Multivariate analysis (PCA/FA and cluster analysis) and correlation present important tools for better understanding of the source identification of metals. The results revealed that $\mathrm{Cd}$, Co, and Fe originated from natural and anthropogenic sources; $\mathrm{Cr}$ and $\mathrm{Pb}$ are derived from natural sources; and $\mathrm{Mn}$ is controlled by anthropogenic sources. As there is a lack of information on the distribution of metals spatially in the Batang Arau River, these results could help develop water management and conservation strategies as well as an effective monitoring program for this river.

\section{Acknowledgments}

The authors would like to thank Faculty of Engineering, Universitas Andalas, Indonesia (Grand No. 001/PL/SPK/PNP/ FT-Unand/2014) and Research Institution and Community Service, Universitas Andalas, Indonesia (Grand No.15/H.15/ FUNDAMENTAL/LPPM/2015) for supporting this work. Submitted for publication January 4, 2015; accepted for publication September 25, 2017.

\section{References}

American Public Health Association, American Water Works Association, Water Environment Federation (1998) Standard Methods for the Examination of Water and Wastewater, Eaton, A. D., Clesceri, L. S., Greenberg, A. E., Franson, M. A., Eds.; 20th ed.; American Public Health Association: Washington, D.C.

Caccia, G. V.; Millero, J. F.; Palanques, A. (2003) The Distribution of Trace Metals in Florida Bay Sediments. Mar. Poll. Bull., 46, 1420-1433.

Delgado, J.; Nieto, J. M.; Boski, T. (2010) Analysis of the Spatial Variation of Metals in the Guadiana Estuary Sediments (SW Iberian Peninsula) Based on GIS-Mapping Techniques. Estuarine Coastal Shelf Sci., 88, 71-83.

Environmental Impact Management Agency of Padang City (2013) Annual Report; Padang, Indonesia.

Forstner, U.; Wittmann, G. T. W. (1979) Metal Pollution in the Aquatic Environment; Springer-Verlag: Berlin.
Helard, D.; Fajri, A. J.; Setyawan, A. S.; Li, F.; Yamada, T.; Horio, A.; Huang, M.; Kawaguchi, T. (2012) Formation and Role of Bacterial Community in the Sediment Bed of Open Channel Receiving Johkasou Effluent: Multivariate Statistical Analysis Interpretation. Proc. Environ. Sanit. Eng. Res, 68 (7), III_1-III_11.

Hong, P. C.; Aweng, E. R.; Hermansah, H. (2012) Pollution Sources, Beneficial Uses and Management of Batang Arau and Kuranji River in Padang, Indonesia. J. Appl. Sci. Environ. Sanit., 7 (3), 221-230.

Jiang, Y.; Ding, Z.; Peng, Q.; Liao, J.; Leting, L. (2012) Spatial Distribution and Corresponding Factors of Metals Concentrations in the Dongjiang River Basin, Southeast China. Res. J. Environ. Earth Sci., 4 (4), 448-459.

Johnes, P. J.; Heathwaite, A. L. (1997) Modelling the Impact of Land Use Change on Water Quality in Agricultural Catchments. Hydrol. Processes, 11 (3), 269-286.

Kannel, P. R.; Lee, S.; Kanel, S. R.; Khan, S. P.; Lee, Y. S. (2007) Spatial Temporal Variation and Comparative Assessment of Water Qualities of Urban River System: A Case Study of the River Bagmati (Nepal). Environ. Monit. Assess., 129, 433-459.

Krishna, A. K.; Satyanarayanan, M.; Govil, P. K. (2009) Assessment of Heavy Metal Pollution in Water Using Multivariate Statistical Techniques in an Industrial Area: A Case Study from Patancheru, Medak District, Andhra Pradesh, India. J. Hazard. Mater., 167, 366-373.

Manoj, K.; Padhy, P. K. (2014) Multivariate Statistical Techniques and Water Quality Assessment: Discourse and Review on Some Analytical Models. Int. J. Environ. Sci., 5 (3), 607-626.

National Standardization Agency of Indonesia (2008) Indonesian National Standard: Water and wastewater - Section 57: Sampling methods for surface water; SNI 6989.57-2008; Jakarta, Indonesia.

Padang Statistic Center (2009) Padang in Figures; Padang, Indonesia.

Pejman, A. H.; Nabi Bidhendi, G. R.; Karbassi, A. R.; Mehrdadi, N.; Esmaeli Bidhendi, M. (2009) Evaluation of Spatial and Seasonal Variations in Surface Water Quality Using Multivariate Statistical Techniques. Int. J. Environ. Sci. Technol., 6 (3), 467-476.

Reid M. K.; Spencer K. L. (2009) Use of Principal Components Analysis (PCA) on Estuarine Sediment Datasets: The Effect of Data Pre-Treatment. Environ. Poll., 157, 2275-2281.

Shrestha, S.; Kazama, F. (2007) Assessment of Surface Water Quality Using Multivariate Statistical Techniques: A Case Study of the Fuji River Basin, Japan. Environ. Modell. Software, 22, 464-475.

Simeonov, V.; Stratis, J. A.; Samara, C.; Zachariadis, G.; Voutsa, D.; Anthemidis, A.; Sofoniou, M.; Kouimtzis, T. (2003) Assessment of the Surface Water Quality in Northern Greece. Water Res., 37 (17), 4119-4124.

Singh, K. P.; Malik, A.; Sinha, S. (2005) Water Quality Assessment and Apportionment of Pollution Sources of Gomti River (India) Using Multivariate Statistical Techniques: A Case Study. Anal. Chim. Acta, 538, 355-374.

Suthar, S.; Nema, K. A.; Chabukdhara, M.; Gupta, K. S. (2009) Assessment of Metals in Water and Sediments of Hindon River, India: Impact of Industrial and Urban Discharges. J. Hazard. Mater., 171, 1088-1095.

TRI91 (1993) Toxics Release Inventory Program; U.S. Environmental Protection Agency.

U.S. EPA (2006) National Recommended Water Quality Criteria; U.S. Environmental Protection Agency.

U.S. EPA (2009) National Primary Drinking Water Regulations; EPA 816-F-09-004; U.S. Environmental Protection Agency.

Varol, M.; Şen, B. (2009) Assessment of Surface Water Quality Using Multivariate Statistical Techniques: A Case Study of Behrimaz Stream, Turkey. Environ. Monit. Assess., 159, 543-553.

Varol, M.; Şen, B. (2012) Assessment of Nutrient and Heavy Metal Contamination in Surface Water and Sediments of the Upper Tigris River, Turkey. Catena, 92, 1-10.

Varol, M.; Gökot, B.; Bekleyen, A. (2013) Dissolved Metals in Tigris River (Turkey): Spatial and Temporal Variation. Environ. Sci. Poll. Res., 20, 6096-6108.

WHO (2004) Guidelines for Drinking Water Quality, 3. World Health Organization, Geneva. 
Xing, W.; Liu, G. (2011) Iron Biogeochemistry and its Environmental Impacts in Freshwater Lakes. Fresenius Environ. Bull., 20 (6), 1339-1345.

Zare, G. A.; Sheikh, V.; Sadoddin, A. (2011) Assessment of Seasonal Variations of Chemical Characteristics in Surface Water Using Multivariate Statistical Methods. Int. J. Environ. Sci. Technol., 8 (3), 581-592. 
Author Profile

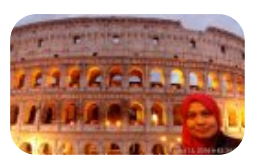

SHINTA INDAH

Universitas Andalas

Environmental Engineering

SINTA ID : 259373

Subjects/Areas:

ID

Teknik Lingkungan Kimia Air Pengelolaan Kualitas Air

\section{Cîinta}

\subsection{5}

Overall Score

\subsection{9}

3 Years Score

\section{9}

Overall Score V2

\section{8}

3 Years Score V2

1

Books

\section{4}

Rank in National

\section{1}

3 Years National Rank

6

IPR

Scoring $\theta$

\section{2}

Rank in Affiliation

\section{7}

3 Years Affiliation Rank

Search..

a

Filter by type: Journal Proceeding Book Other $\$$ All 
Q2 Utilization of maize husk (Zea mays L.) as low-cost adsorbent in removal of iron from aqueous soluti Water Science and Technology I vol: 73 I issue : 12 | 2016-06-01 | Journal

Q2 Studies on desorption and regeneration of natural pumice for iron removal from aqueous solution

Q2 Water Science and Technology I vol: 2017 I issue : 2 | 2017-01-01 | Journal

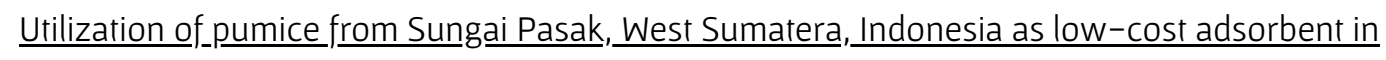

Q4 $\underline{\text { removal o }}$

AIP Conference Proceedings | vol: 1823 | issue : | 2017-03-17 | Conference Proceedin

Q3 Spatial variation of metals in the Batang Arau River, West Sumatera, Indonesia

Water Environment Research I vol: 90 I issue : 3 | 2018-03-01 | Journal

Spatial distribution of coliform bacteria in Batang Arau River, Padang, West Sumatera, Indonesia

Q3 IOP Conference Series: Materials Science and Engineering I vol: 602 I issue : 1 | 2019-09-06 I Conference Proceedin

\section{Column study of aluminum adsorption from groundwater by natural pumice}

Q2 International Journal on Advanced Science, Engineering and Information Technology I vol: 9 | issue : 5 | 2019-01-01 | Journal Q3 Removal of nitrate from groundwater by column using.pumice as adsorbent as an eff.fort for water

IOP Conference Series: Materials Science and Engineering | vol: 846 | issue : 1| 2020-05-27 | Conference Proceedin Q3 Spatial variability_of ammonium, nitrite and nitrate concentrations in water of Batang Arau River, Water Science and Technology: Water Supply | vol: 20 | issue : 4 | 2020-06-01 | Journal

Page 1 of 1 | Total Records : 9 